Tropical Journal of Pharmaceutical Research October 2019; 18 (10): 2147-2154

ISSN: 1596-5996 (print); 1596-9827 (electronic)

(1) Pharmacotherapy Group, Faculty of Pharmacy, University of Benin, Benin City, 300001 Nigeria.

\title{
Morphological characterization, phytochemical profile, and cytotoxic and insecticidal activities of diverse parts of Bryophyllum pinnatum (Lam.)
}

\author{
Talal Shaheer ${ }^{1}$, Syed Tahir Ali ${ }^{1}$, Ghazala Hafeez Rizwani ${ }^{1}$, Muhammad Naeem \\ Qaisar $^{2}$, Khizar Abbas ${ }^{3 *}$, Muhammad Imran Qadir ${ }^{4}$, Faheem Ahmad Siddique ${ }^{5}$ \\ ${ }^{1}$ Department of Pharmacognosy, Faculty of Pharmacy, Hamdard University, Karachi, ${ }^{2}$ College of Pharmacy, University of \\ Sargodha, Sargodha, ${ }^{3}$ Department of Pharmacognosy, Faculty of Pharmacy, ${ }^{4}$ Institute of Molecular Biology \& Biotechnology, \\ Bahuddin Zakariya University, Multan, ${ }^{5}$ Department of Pharmacy, University of Central Punjab, Lahore, Pakistan
}

*For correspondence: Email: khizarabbas@bzu.edu.pk; Tel: +92-3228832872

Sent for review: 15 December 2018

Revised accepted: 20 September 2019

\begin{abstract}
Purpose: To standardize Zakham-e-Hayat (Bryophyllum pinnatum Lam.) as well as determine its cytotoxic and insecticidal activity.

Methods: Different parts of the plant (flowers, young leaves, old leaves and stem) and different solvents, viz, methanol, ethyl acetate and n-hexane were used for the extraction. Morphological characterization (macroscopic and microscopic), phytochemical screening for primary and secondary metabolites, and thin layer chromatography (TLC) using various solvent systems, namely, methanol/chloroform ( $\left.\mathrm{MeOH} / \mathrm{CHCl}_{3}\right)$, n-hexane/methanol/chloroform (n-hexane/MeOH/CHCl 3 ), methanol/chloroform/water ( $\mathrm{MeOH} / \mathrm{CHCl}_{3} / \mathrm{H}_{2} \mathrm{O}$ ), n-hexane/chloroform (n-hexane/ $\mathrm{CHCl}_{3}$ ), n-hexane/ethyl acetate ( $n$-hexane/EtOAc) were carried out. Fourier transform infrared spectroscopy (FTIR) was also performed. In addition, the extracts were evaluated for their cytotoxic and insecticidal activities.

Results: The methanol fraction of the young leaves had $50 \%$ lethal dose $\left(L D_{50}\right)$ of $28.46 \mu \mathrm{g} / \mathrm{mL}$ while the ethyl acetate fraction of young and old leaves showed significant cytotoxicity at $L D_{50}$ of $0.13 \mu \mathrm{g} / \mathrm{mL}$ and $142.68 \mu \mathrm{g} / \mathrm{mL}$ respectively. On the other hand, $n$-hexane fraction was inactive. The methanol fraction of the flower revealed the presence of carbohydrates, the ethyl acetate fraction showed the presence of carbohydrates and amino acids, while the n-hexane fraction showed the presence of carbohydrates as primary metabolites. Furthermore, alkaloids, flavonoid, saponins and resins were present in the methanol fraction, flavonoid and alkaloids in the ethyl acetate fraction, and alkaloids and resins in the $n$-hexane fraction as secondary metabolites.

Conclusion: Methanol and $n$-hexane fractions of Bryophyllum pinnatum have some safe bioactive compounds which may exhibit potential health benefits.
\end{abstract}

Keywords: Bryophyllum pinnatum (Lam.), Phytochemical, Histology, Insecticidal, Toxicology

This is an Open Access article that uses a fund-ing model which does not charge readers or their institutions for access and distributed under the terms of the Creative Commons Attribution License (http://creativecommons.org/licenses/by/4.0) and the Budapest Open Access Initiative (http://www.budapestopenaccessinitiative.org/read), which permit unrestricted use, distribution, and reproduction in any medium, provided the original work is properly credited.

Tropical Journal of Pharmaceutical Research is indexed by Science Citation Index (SciSearch), Scopus, International Pharmaceutical Abstract, Chemical Abstracts, Embase, Index Copernicus, EBSCO, African Index Medicus, JournalSeek, Journal Citation Reports/Science Edition, Directory of Open Access Journals (DOAJ), African Journal Online, Bioline International, Open-J-Gate and Pharmacy Abstracts

\section{INTRODUCTION}

Drug discovery using natural products is a challenging task for designing new products.
Despite the recent increase in the use of plantbased medicines, no attention has been given to the safety and efficacy of herbs. Less than $10 \%$ of herbal drugs in the world are standardized to 
know active components. Therefore, standardization and quality control are essential to both the raw material and medicinal preparations of plants [1,2]. Plants produce phytochemicals that protect them from herbivores and these constitutes are also toxic to humans [3]. Due to this reason, toxicological assessment of plant-based drugs is important [4].

Bryophyllum pinnatum (Lam.), family Crassulaceae, commonly known as Zakham-ehayat [5], is widely distributed throughout the world and has been used in folkloric medicine in tropical Africa, tropical America, India, China, and Australia.

Its various morphological parts contain valuable constituents such as alkaloids, phenols, flavonoids, saponins, tannins, carotenoids, triterpenes, cardinolides, steroids, lipids, macro elements (magnesium, calcium, potassium, phosphorus, sodium) and microelements (iron, zinc, ascorbic acid, thiamine, niacin), bryotoxin $A$, bryotoxin B, 24-epiclerosterol, isofucosterol, bryophollone, a-amyrin, $\beta$-amyrin, ferulic acid, caffeic acid, malic acid, $p$-coumaric acid, syringic acid, isocitric acid, p-hydroxy benzoic acid, kaemferol, sitosterol, quercitin, $n$-tritiacontane, palmitic acid, stearic acid and behenic acid [5-7].

The plant is applied to wounds, boils, bites of insects, for treatments of earache, burns, abscesses, ulcers, diarrhea, lithiasis [8], and has anti-leishmanial, anti-diabetic, anti-depressant, anti-inflammatory, uterine relaxant, diuretic, anticonvulsant, and neuro-pharmacological potential [7,9-11].

Keeping in view of its importance, this research was planned to standardize the Bryophyllum pinnatum (Lam.) for the development of monograph, established safety profile through insecticidal and toxicological studies.

\section{EXPERIMENTAL}

\section{Collection and identification of plant}

The plant parts of Bryophyllum pinnatum (Lam) were collected from the vicinity of the University of Karachi, Karachi, Pakistan, between May and July 2014. The plant was identified by Prof. Dr. Ghazala H. Rizwani, Dean Faculty of Pharmacy and Pharmaceutical Sciences, University of Karachi, Karachi. A voucher specimen (No. 192014/PCOG/KU) was deposited in the herbarium of the Department of Pharmacognosy, Faculty of Pharmacy and Pharmaceutical Sciences, University of Karachi, for future reference.

\section{Extraction and fractionation}

The flowers $(100.0 \mathrm{~g}$ ), leaves (young $150.0 \mathrm{~g}$ each of young and old leaves), and the stem $(200.0 \mathrm{~g})$ of Bryophyllum pinnatum (Lam.) were separated, washed with tap water and air dried. After drying, the separated parts were macerated in $70 \%$ methanol at room temperature for 7 days in separate glass containers with occasional shaking. After that, each extract was filtered through Whatmann's filter paper No. 1. The solvent was evaporated under reduced pressure and controlled temperature in rotary evaporator (BUCHI Rotavapour R-200, Switzerland). Reddish brown (flowers), dark brown (young and old leaves), and greenish black (stem) extracts were obtained.

The gummy methanolic extracts of each of the four parts of the plant were first partitioned using $n$-hexane $(10 \mathrm{~mL})$ and methanol $(10 \mathrm{~mL})$. The separating funnel containing the extracts and solvents were allowed to stand for $2 \mathrm{~h}$. The lower layer of the methanol extract and upper layer of $n$-hexane extract were collected separately. Then in the methanolic fraction, $10 \mathrm{~mL}$ of ethyl acetate was added and allowed to stand for $2 \mathrm{~h}$. After that, the fractions of methanol (upper layer) and ethyl acetate (lower layer) were collected separately and shade dried.

\section{Macroscopic and microscopic studies}

Bryophyllum pinnatum (Lam.) flowers, leaves, and stem were observed for size, shape, texture, color and odor. Anatomical studies were performed by fixing samples of flowers, leaves and stem for $48 \mathrm{~h}$ in formalin-acetic acid solution. Then, this material was transferred to the solution of ethanol $(75 \%)$ and acetic acid $(25 \%)$ known as acetic-alcohol for storage for a long period of time. Freehand sectioning technique was used for cutting the section. Fast green and double stained safranine techniques were used to prepare the permanent slides by serial dehydration in ethanol. Binocular microscope was used to observe the slides [12].

Powder microscopy of leaves and stem was performed by placing small quantities of fine powder on glass slides separately, and 2 drops of chloral hydrate solution was added on each slide. Then, the powdered material and chloral hydrate were mixed thoroughly with the help of a fine needle. The slides were cleaned by using the fine blotting paper after placing the glass cover slip on the slide. Binocular microscope was used to observe the tissues and their organisations [13]. 


\section{Phytochemical screening}

The phytochemical screening for primary and secondary metabolites was performed according to the standard protocols $[14,15]$.

\section{Thin layer chromatography}

Thin layer chromatography (TLC) for different fractions (methanol, ethyl acetate and $n$-hexane) of different parts (flower, young leaves, old leaves and stem) with different solvent systems methanol/chloroform $\left(\mathrm{MeOH} / \mathrm{CHCl}_{3}\right)$ in a ratio of 7:3, $n$-hexane/methanol/chloroform (n-hexane/ $\mathrm{MeOH} / \mathrm{CHCl}_{3}$ ) in a ratio of $7: 2: 1$, methanol/ chloroform/water $\left(\mathrm{MeOH} / \mathrm{CHCl}_{3}, \mathrm{H}_{2} \mathrm{O}\right)$ in a ratio of 7:2:1, $n$-hexane/chloroform ( $n$-hexane/ $\mathrm{CHCl}_{3}$ ) in a ratio of $6: 4, n$-hexane/ethyl acetate $(n$ hexane/EtOAc) in a ratio of 9.5: 0.5, were performed by using the method used by Stahl (1967) [16].

\section{Fourier transform infrared spectroscopy (FTIR)}

Fourier transform infrared spectroscopy (FTIR) was performed with the help of Nicolet Avatar 330 (FT-IR by Thermo Electron Corporation, USA) by using the standard method mentioned in the manual guide. This spectroscopic technique was used for the verification of various components present in the plants by recognizing the functionally acting groups appeared in the specific region of the spectrum.

\section{Brine shrimp lethality assay}

The rectangular hatching tray $(22 \times 32 \mathrm{~cm}$ in diameter) was filled with filtered brine solution and $50 \mathrm{mg}$ of shrimp's eggs were added to it and the tray was incubated at $37^{\circ} \mathrm{C}$ to hatch for two days. Then, $20 \mathrm{mg}$ of each extract was dissolved in $2 \mathrm{~mL}$ of respective solvent and transferred to vials of 5,50 and $500 \mu \mathrm{L}$. The vials were allowed to stand overnight, so that, the solvent gets evaporated. Then 10 larvae were added to each vial with the help of Pasteur pipette. Sea water was added to the vials to make final volume up to $5 \mathrm{~mL}$.

The vials were placed in an incubator at 25-27 ${ }^{\circ} \mathrm{C}$ and incubated for $24 \mathrm{~h}$ under illumination. The other vials were filled with dimethyl sulfoxide (solvent) and etoposide (reference cytotoxic drug) which were used as a negative and positive control respectively. The data obtained was analyzed with the help of computer program, 'Finney to determine $\mathrm{LD}_{50}$ with $95 \%$ confidence interval $[17,18]$.

\section{Insecticidal assay}

Two insects, namely, Tribolium castaneum and Rhyzopertha dominica, were obtained from H.E.J Research Institute of Chemistry and Dr Panjwani Center for Molecular Medicine and Drug Research, University of Karachi, Karachi, Pakistan. Toxicity was determined by contact method. Permethrin and dimethyl sulfoxide were used as positive and negative control respectively. Aliquots of $0.7 \mathrm{ml}$ at the concentration of $1019.10 \mu \mathrm{g} / \mathrm{cm}^{2}$ were used for the impregnation of filter paper Whatman No. 1. After drying of $5 \mathrm{~min}$, filter papers were inserted at the bottom of the Petri dishes $(5.5 \mathrm{~cm}$ diameter $\times 1.2 \mathrm{~cm}$ ) containing culture media and then ten adult un-sexed Tribolium castaneum and Rhyzopertha dominica were added to separate Petri dishes under the same environmental conditions, and six replicates were tested. The inner side of the lid was coated with Vaseline to prevent insect staying on the lid. The insects were considered dead when no antenna or leg movement was detected when gently touched with a brush. Mortality was recorded after $24 \mathrm{~h}$ of treatment using Eq 1 [17].

$M(\%)=($ IST $/$ ISC $) 100$

where $M$ is mortality, IST and ISC are the number of insects that survived in the test and control.

\section{RESULTS}

\section{Morphological features}

Macroscopic analysis showed that flowers were pinkish red, soft and tubular; leaves were green, non-aromatic, bitter, simple, pinnate and fleshy, while the stem was greenish purple nonaromatic, astringent, round and glabrous. Results for histological study of flowers, leaves, and the stem are shown in Figure 1, Figure 2 and Figure 3. Histological study of the flowers revealed the presence of upper and lower epidermis, spongy cells and color pigments. Transverse section of leaf showed the presence of upper and lower epidermis covered with cuticle and contain anisocytic type of stomata. Just beneath the epidermis there was a parenchymatous cell present with deposition of starch grains.

Collateral vascular bundles were present and the mesophyll region was composed of similar sized cells of cholrenchyma and spongy parenchyma. Transverse section of stem showed that there is an outer layer of thick-walled epidermis covered with cuticle. Beneath the epidermis, there was a three-layered hypodermis made up of 
sclerenchymatous cells. The inner cortex consisted of thin walled parenchymatous cells, which were loosely arranged with deposition of starch grains. In the middle region, vascular bundles were arranged in a ring. Xylem elements were mainly in the form of tracheids with few vessels of xylem parenchyma fibers. Pith region consists of parenchymatous cell in the center showed the deposition of starch grains and calcium oxalate crystal. Results for powder microscopy are given in Figure 4 and Figure 5. The powder microscopy indicates the presence of spongy parenchyma with chlorophyll, annual vessel, xylem vessel, a fibre attached to parenchyma cell, epidermal cell, cork cell with fibres, epidermal cells with fibre, patches of fibre, cork cell, pitted vessel and spiral vessels.

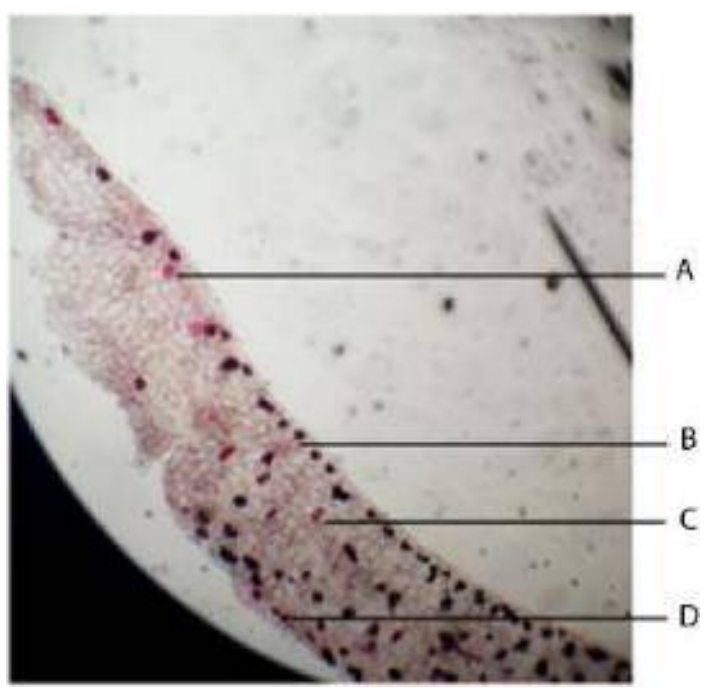

Figure 1: Histology of Flower. A: Upper epidermis, B: Color pigment C: Spongy cell, D: Lower epidermis

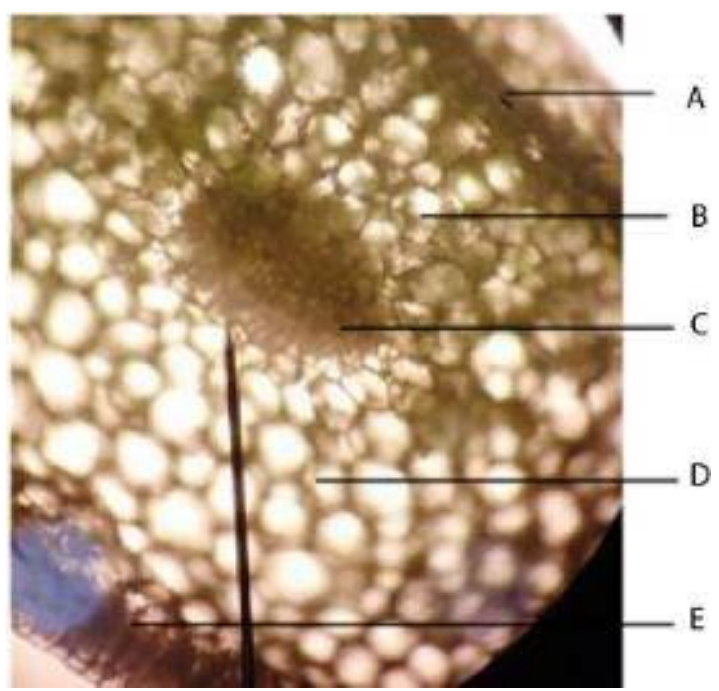

Figure 2: Histology of Leaf. A: Upper epidermis, B: Parenchymatous cells, C: Vascular bundle, D: Mesophyll region, E: Lower epidermis

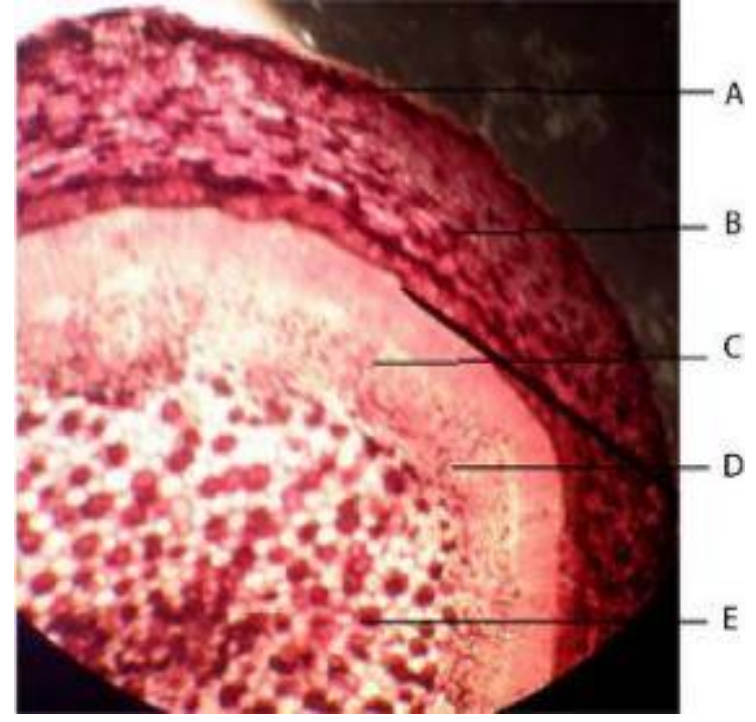

Figure 3: Histology of Stem. A: Epidermis, B: Cortical region, C: Phloem. D: Xylem, E: Pith

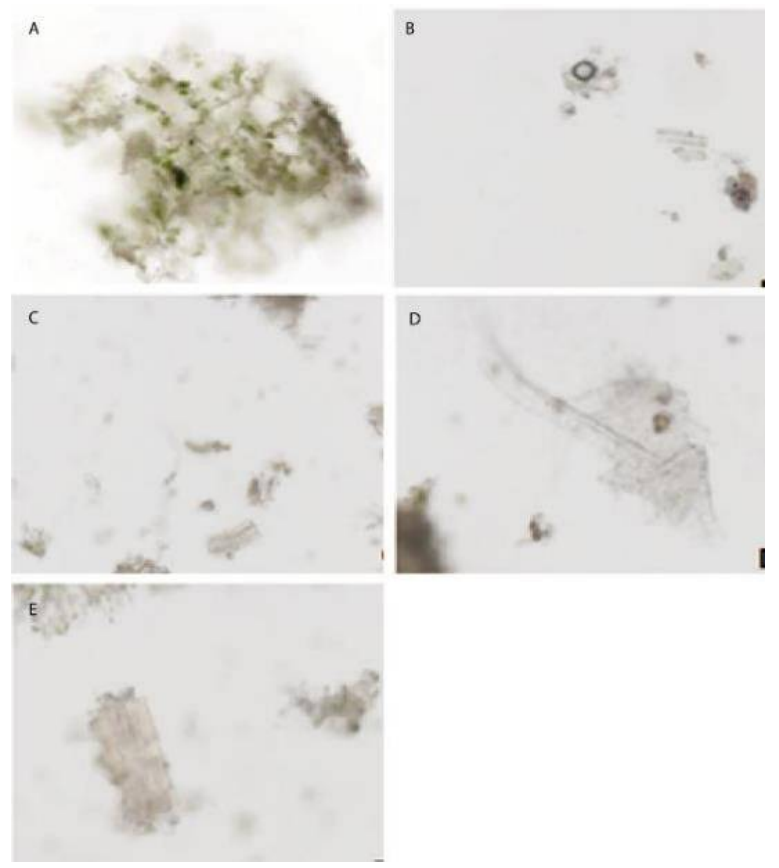

Figure 4: Powder microscopy of Bryophyllum Pinnatum (Lam) leaves. A: Spongy parenchyma with chlorophyll, B: Annual vessel, C: Xylem vessel, D: Fibre attached with parenchyma cell, E: Epidermal cell

Table 1 shows the phytochemical analysis of different extracts of flowers, young leaves, old leaves and stem. The phytochemical study of the methanolic fraction of flowers revealed the presence of carbohydrates; the ethyl acetate fraction showed the presence of carbohydrates and amino acids; and the $n$-hexane fraction showed the presence of carbohydrates as primary metabolites. Whereas, alkaloids, flavonoid, saponins and resins were present in the methanolic fraction; flavonoid and alkaloids in 
the ethyl acetate fraction; alkaloids and resins in the $n$-hexane fraction as secondary metabolites.

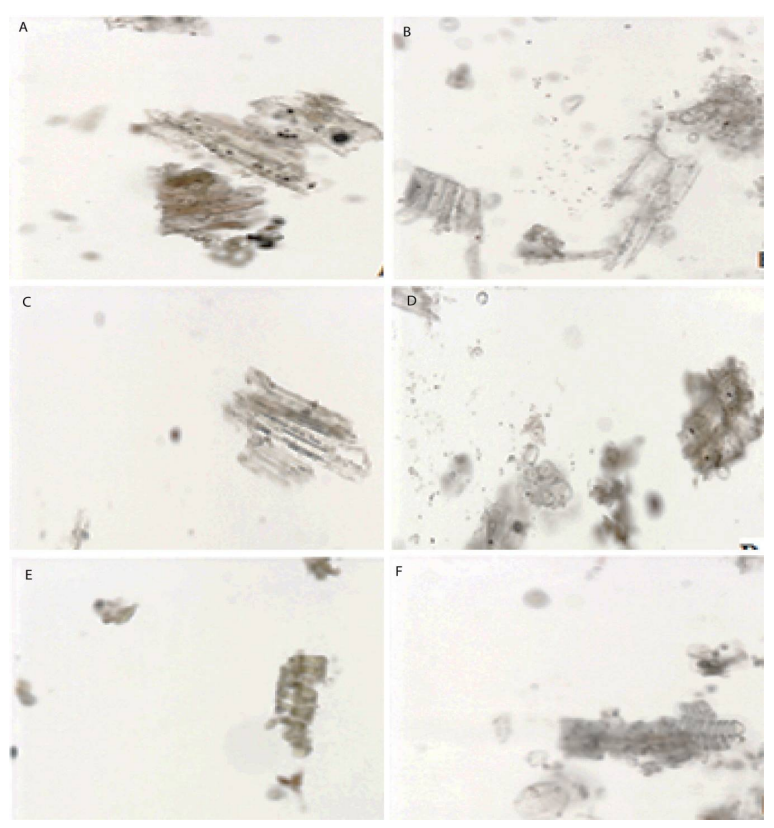

Figure 5: Powder microscopy of Bryophyllum pinnatum (Lam.) stem. A: Cork cell with fibre, B: Epidermal cells with fibre, C: Patches of fibre, D: Cork cell, E: Pitted vessel F:annular and spiral vessel

The phytochemical results for the young leaves showed that the methanolic fraction contained carbohydrates; while the ethyl acetate and the $n$ hexane fraction contained carbohydrates and amino acids as primary metabolites. Whereas, alkaloids, flavonoid, saponins, tannins and resins were present in the methanolic fraction; alkaloids, flavonoids and saponins in the ethyl acetate fraction; and alkaloids and resins were present in the $n$-hexane fraction, as secondary metabolites. The methanolic fraction of old leaves revealed the presence of carbohydrates and amino acids; the ethyl acetate fraction showed the presence of carbohydrates; and the $n$-hexane fraction revealed the presence of carbohydrates and amino acids as primary metabolites. On the other hand, alkaloids, flavonoids, saponins, tannins and resins were present in the methanolic fraction; alkaloids and tannins in the ethyl acetate fraction; and alkaloids and resins in the $n$-hexane fraction as secondary metabolites.

The phytochemical results for methanol and the ethyl acetate fractions of stem revealed the presence of carbohydrates and amino acids; the $n$-hexane fraction showed the presence of carbohydrates as primary metabolites. Whereas alkaloids, saponins and resins were present in the methanolic fraction as secondary metabolites, alkaloids, saponins and tannins in the ethyl acetate fraction; and alkaloids, flavonoids and resins in $n$-hexane fraction.

Table 2 shows comparative thin layer chromatographic (TLC) analysis of flower, young leaves, old leaves and stem. TLC analysis of different fractions (methanol, ethyl acetate, $n$ hexane) in different solvent systems $\mathrm{MeOH} / \mathrm{CHCl}_{3} \quad(7: 3), \quad n$-hexane/MeOH$/ \mathrm{CHCl}_{3}$ (7:2:1), $\quad \mathrm{MeOH} / \mathrm{CHCl}_{3} / \mathrm{H}_{2} \mathrm{O} \quad(7: 2: 1)$, $\quad n-$ hexane/ $\mathrm{CHCl}_{3}$ (6:4), n-hexane/Ethyl acetate (9.5:0.5) of flower showed different compounds with Rf values $0.9,0.14,0.40,0.44,0.48,0.5$, $0.65,0.2,0.5,0.7,0.8,0.26,0.45,0.56,0.57$, 0.85 , whereas, chromatographic analysis of young leaves showed nine different components with $\mathrm{Rf}$ values $0.59,0.69,0.72,0.8,0.83,0.9$, $0.26,0.45,0.56$. Thin layer chromatographic analysis of old leaves extracts (methanol, ethyl acetate, $n$-hexane) in different solvent systems: $\mathrm{MeOH} / \mathrm{CHCl}_{3} \quad(7: 3), \quad n$-hexane/MeOH$/ \mathrm{CHCl}_{3}$ (7:2:1), $\quad \mathrm{MeOH} / \mathrm{CHCl}_{3} / \mathrm{H}_{2} \mathrm{O} \quad(7: 2: 1), \quad n-$ hexane/ $\mathrm{CHCl}_{3}$ (6:4), n-hexane/Ethyl acetate (9.5:0.5) showed different components having $\mathrm{Rf}$ values $0.47, \quad 0.56,0.60, \quad 0.72, \quad 0.79, \quad 0.05$, $0.1,0.2,0.3,0.5,0.55,0.7,0.8,0.26,0.45,0.56$, $0.4,0.5,0.58,0.69$, whereas, chromatographic analysis of stem revealed the presence of different components with different Rf values 0.5, $0.6,0.8,0.59,0.61,0.69,0.76,0.22,0.68,0.80$, $0.28,0.3,0.4,0.7$.

Table 1: Phytochemical profile of various extracts of flowers, young leaves, old leaves and stem

\begin{tabular}{|c|c|c|c|c|c|c|c|c|c|c|c|c|}
\hline \multirow{2}{*}{$\begin{array}{l}\text { Phyto- } \\
\text { constituent }\end{array}$} & \multicolumn{3}{|c|}{ Flowers } & \multicolumn{3}{|c|}{ Young leaves } & \multicolumn{3}{|c|}{ Old leaves } & \multicolumn{3}{|c|}{ Stem } \\
\hline & Methanol & $\begin{array}{l}\text { Ethyl } \\
\text { acetat } \\
\text { e }\end{array}$ & $\begin{array}{c}n- \\
\text { Hexane }\end{array}$ & Methanol & $\begin{array}{l}\text { Ethyl } \\
\text { acetat } \\
\text { e }\end{array}$ & $\begin{array}{c}n- \\
\text { Hexane }\end{array}$ & Methano & $\begin{array}{l}\text { Ethyl } \\
\text { acetat } \\
\text { e }\end{array}$ & $\begin{array}{c}n- \\
\text { Hexane }\end{array}$ & Methanc & $\begin{array}{l}\text { Ethyl } \\
\text { acetat } \\
\text { e }\end{array}$ & $\begin{array}{c}n- \\
\text { Hexane }\end{array}$ \\
\hline $\begin{array}{l}\text { Carbohydrate } \\
\text { s }\end{array}$ & +++ & +++ & +++ & +++ & +++ & ++ & +++ & +++ & ++ & +++ & ++ & +++ \\
\hline Amino acid & - & - & - & _- & + & ++ & +++ & ++ & ++ & - & - & - \\
\hline Alkaloids & +++ & +++ & +++ & +++ & +++ & +++ & +++ & +++ & +++ & +++ & +++ & +++ \\
\hline Flavonoids & ++ & ++ & - & +++ & ++ & - & -- & - & - & - & - & ++ \\
\hline Saponins & +++ & - & - & +++ & +++ & - & +++ & - & - & +++ & +++ & - \\
\hline Tannins & - & - & - & +++ & +++ & - & ++ & ++ & - & - & +++ & - \\
\hline Resins & +++ & - & +++ & +++ & +++ & +++ & +++ & - & +++ & ++ & +++ & +++ \\
\hline
\end{tabular}


Table 2: Comparative TLC profile of flower, old leaves, young leaves and stem using various solvent systems

\begin{tabular}{|c|c|c|c|c|c|c|c|c|}
\hline \multirow[t]{2}{*}{ Solvent } & \multicolumn{2}{|c|}{ Flower } & \multicolumn{2}{|c|}{ Old leaves } & \multicolumn{2}{|c|}{ Young leaves } & \multicolumn{2}{|c|}{ Stem } \\
\hline & $\begin{array}{l}\text { No. of } \\
\text { compound }\end{array}$ & $R_{f}$ Value & $\begin{array}{c}\text { No. of } \\
\text { compound }\end{array}$ & $\boldsymbol{R}_{f}$ Value & $\begin{array}{l}\text { No. of } \\
\text { compound }\end{array}$ & $R_{f}$ Value & $\begin{array}{c}\text { No. of } \\
\text { compound }\end{array}$ & $R_{f}$ Value \\
\hline $\begin{array}{l}\mathrm{MeOH} / \mathrm{CHCl}_{3} / \\
\mathrm{H}_{2} \mathrm{O}(7: 2: 1)\end{array}$ & 7 & $\begin{array}{l}\text { 0.9,0.14,0.40, 0.44, } \\
0.48,0.5,0.65\end{array}$ & 02 & $0.58,0.69$ & 3 & $\begin{array}{l}0.59,0.69, \\
0.72\end{array}$ & 04 & $\begin{array}{l}0.59,0.61 \\
0.69,0.76\end{array}$ \\
\hline $\begin{array}{l}n \text {-hexane } / \mathrm{CHCl}_{3} \\
(6: 4)\end{array}$ & - & - & 09 & $\begin{array}{l}0.05,0.1,0.2,0.3,( \\
0.55,0.6,0.7,0.8\end{array}$ & - & - & 05 & $\begin{array}{l}0.28,0.3,0.4, \\
0.6,0.7\end{array}$ \\
\hline $\begin{array}{l}\mathrm{MeOH} / \mathrm{CHCl}_{3} \\
(7: 3)\end{array}$ & 2 & $0.57,0.85$ & 05 & $\begin{array}{l}0.47,0.56,0.60 \\
0.72,0.79\end{array}$ & 2 & $\begin{array}{l}0.8 \\
0.83\end{array}$ & 03 & $\begin{array}{l}0.22,0.68 \\
0.80\end{array}$ \\
\hline $\begin{array}{l}\text { n-hexane/MeOH/ } \\
\mathrm{CHCl}_{3}(7: 2: 1)\end{array}$ & 5 & $0.2,0.5,0.7,0.8,0 . \subseteq$ & 05 & $\begin{array}{l}0.4,0.5,0.6 \\
0.7,0.8\end{array}$ & 1 & 0.9 & 03 & $0.5,0.6,0.8$ \\
\hline $\begin{array}{l}n \text {-hexane/E. acetat } \\
(9.5: 0.5)\end{array}$ & 4 & $0.2,0.26,0.45,0.56$ & 05 & $\begin{array}{l}0.2,0.26,0.45,0.5 € \\
0.72\end{array}$ & 3 & $\begin{array}{l}0.26,0.45 \\
0.56\end{array}$ & - & - \\
\hline
\end{tabular}

Fourier transform infrared spectroscopy (FTIR) of the methanolic, the ethyl acetate and the $n$ hexane fraction of different parts of the plant are given in Figure 6. Figure $7(\mathrm{a}-\mathrm{d})$ shows the brine shrimp lethality assay (BSLA) of different extract of flower, young leaves, old leaves and stem respectively. None of the extracts showed insecticidal activity.
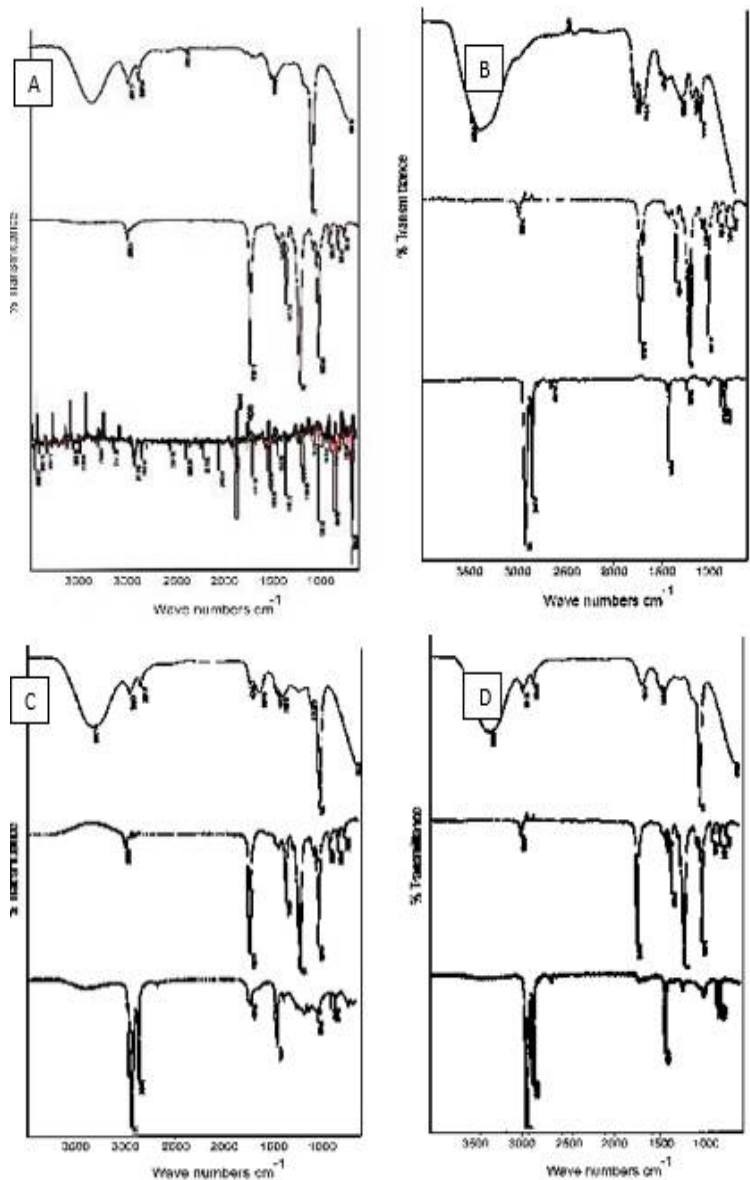

Figure 6: FTIR spectra of Bryophyllum pinnatum: A) Flowers, B) Young Leaves, C) Old leaves, \& D) Stem [For each, methanolic, ethyl acetate and $n$-hexane fraction, respectively]
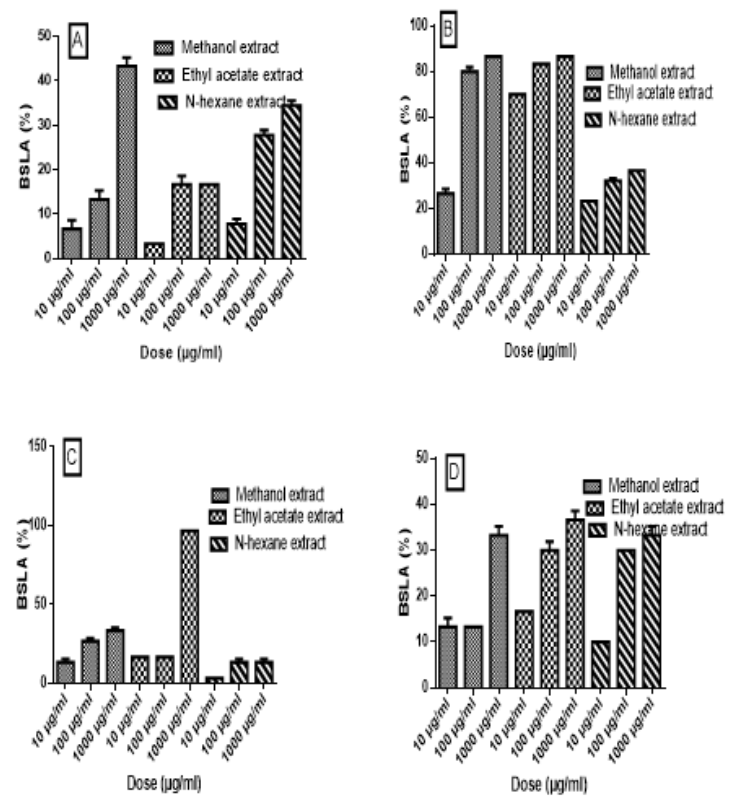

Figure 7: Brine shrimp lethality results for Bryophyllum pinnatum: A) Flowers, B) Young leaves, C) Old leaves, D) Stem

\section{DISCUSSION}

Scientific investigators are working and trying to search those plants which have great medicinal potential. The selected plant in this research has very little scientific literature regarding toxicity. Therefore, it was necessary to conduct research for proper identification and its medicinal effects against various ailments.

The FTIR spectra of the various extracts (methanol, ethyl acetate and $n$-hexane) of flowers, young leaves, old leaves and stem revealed the presence of different chemical moieties/functional groups such as alcohol, ether, ester, carboxylic acid, anhydride, alkane, aldehyde, amine, amide, aromatic and methyl, which indicate that the plant has diverse compounds that may have health benefits for humans. 
Brine shrimp lethality results for methanol, ethyl acetate and $n$-hexane fractions of the flowers showed no cytotoxicity. The methanol extract of young leaves found toxic with $L_{50}$ of 28.4598 $\mu \mathrm{g} / \mathrm{mL}$ while the ethyl acetate extract of young leaves showed maximum lethal effects with $L D_{50}$ of $0.1340 \mu \mathrm{g} / \mathrm{mL}$ while $n$-hexane fraction showed no toxicity. Brine shrimp lethality results for the methanol and $n$-hexane fractions of old leaves were safe as no toxic effects were observed while the ethyl acetate extract of old leaves showed maximum lethal effects with $L_{50}$ of $145.6819 \mu \mathrm{g} / \mathrm{mL}$. The methanol, the ethyl acetate and the $n$-hexane fraction of the stem extract were found safe and no significant toxicity against brine shrimps was observed.

Pesticides are used extensively in grain industry with draw backs of high cost and toxicity. Thus, there is an imperative need to develop pest control techniques which are safer and economical [17,19-21]. The insecticidal activity of the plant extracts (flowers, young leaves, old leaves and stem) was performed by the contact toxicity method. But, unfortunately, no insecticidal activity was observed by any extract.

Bryophyllum pinnatum (Lam.) is although very commonly available in Pakistan and grown throughout the year. Pharmacognostic investigations of the plant with TLC finger prints profile and chemical components/functional groups were verified by Fourier transform infrared radioscopy (FTIR) technique for the first time to prove the plant might be safely useful against a variety of ailments as mentioned in the literature. Flower and stem extracts of Bryophyllum pinnatum (Lam.) showed low toxicity or no toxicity. This suggests that the decoction, which is commonly used in traditional medicine, has no distinct toxic effect [22].

\section{CONCLUSION}

The methanol and $n$-hexane fractions of Bryophyllum pinnatum (Lam.) exhibit low cytotoxic activity, but contain some bioactive compounds which may exhibit potential health benefits.

\section{DECLARATIONS}

\section{Acknowledgement}

The authors are thankful to the Director of Research of Faculty of Pharmacy, Hamdard University, Karachi, Pakistan for providing facilities for this work.

\section{Conflict of interest}

No conflict of interest is associated with this work.

\section{Contribution of authors}

We declare that this work was done by the author(s) named in this article and all liabilities pertaining to claims relating to the content of this article will be borne by the authors. Talal Shaheer contributed to the collection of plant materials, extraction and microscopic analysis. Syed Tahir Ali supervised the chromatographic analysis while Ghazala $\mathrm{H}$. Rizwani originated the idea and supervised the work. Muhammad Naeem Qaisar helped with FTIR while Khizar Abbas collected and analyzed the data and Faheem Ahmad Siddique performed microscopic analysis. Muhammad Imran Qadir prepared the manuscript and provided technical support throughout the project.

\section{Open Access}

This is an Open Access article that uses a funding model which does not charge readers or their institutions for access and distributed under the terms of the Creative Commons Attribution License (http://creativecommons.org/licenses/by/ 4.0) and the Budapest Open Access Initiative (http://www.budapestopenaccessinitiative.org/rea d), which permit unrestricted use, distribution, and reproduction in any medium, provided the original work is properly credited.

\section{REFERENCES}

1. Dolan LC, Matulka RA, Burdock GA. Naturally occurring food toxins. Toxins 2010; 2(9): 2289-2332.

2. Sarwar G, Flora of Pakistan. Crassulaceae,(Eds.): SI Ali \& M. 2002, Qaiser.

3. Kennedy DO, Wightman EL. Herbal extracts and phytochemicals: plant secondary metabolites and the enhancement of human brain function. Adv Nutr 2011; 2(1): 32-50.

4. Ifeoma O, Oluwakanyinsola S. Screening of herbal medicines for potential toxicities. 2013: INTECH Open Access Publisher.

5. Kamboj A, Saluja AK. Bryophyllum pinnatum (Lam.) Kurz.: Phytochemical and pharmacological profile: $A$ review. Pharmacogn Rev 2009; 3(6): 364-374.

6. Patel K, Kumar N, Sharma N. Pharmacognostic \& phytochemical evaluation of Bryophyllum pinnatum leaves. J Adv Sci Res 2011; 2(1): 42-49.

7. Nguelefack $T$, Nana $P$, Atsamo A, Dimo $T$, Watcho $P$, Dongmo A, Tapondjou L, Njamen D, Wansi S, Kamanyi A. Analgesic and anticonvulsant effects of extracts from

Trop J Pharm Res, October 2019; 18(10):2153 
the leaves of Kalanchoe crenata (Andrews) Haworth (Crassulaceae). J Ethnopharmacol 2006; 106(1): 70-75.

8. Begum SS, Gogoi R. Herbal recipe prepared during Bohag or Rongali Bihu in Assam. Indian J Tradit Knowl 2007; 63: 417-422.

9. Ojewole JA. Antinociceptive, anti-inflammatory and antidiabetic effects of Bryophyllum pinnatum (Crassulaceae) leaf aqueous extract. J Ethnopharmacol 2005; 99(1): 13-19.

10. Joseph B, Sridhar S, Sankarganesh J, Edwin BT. Rare medicinal plant-Kalanchoe pinnata. Res $J$ Microbiol 2011; 6(4): 322-327.

11. Patil R, Bhargava $K$, Patel $P$, Singh $K$, Surana J. Diuretic and anti-urolithiatic activity of Hydroalcoholic extract of leaves of Kalanchoe pinnata. J Pharm Res 2009; 7(2): 87-91.

12. Ruzin SE, Plant microtechnique and microscopy. Vol. 198. 1999: Oxford University Press New York.

13. Jackson BP, Snowdon DW, Atlas of microscopy of medicinal plants, culinary herbs and spices. 1990: Belhaven Press.

14. Abbas K, Rizwani GH, Zahid H, Asif A. Pharmacognostic evaluation of Musa paradisiaca $L$. bract, flower, trachea and tracheal fluid. World J Pharm Pharm Sci 2015; 4: 1461-1475.
15. Kokate C, Purohit A, Gokhale S. Pharmacognosy. Nirali Prakashan. 2007. p.635.

16. Stahl E. Thin-layer chromatography. A laboratory handbook. 1967; (2nd edition).

17. Champ B. Methods for detecting pesticide resistance in storage pests. Proc Aust Dev 1981.

18. Alluri V. Krishnaraju TVNR, Sundararaju D, Vanisree $M$, Tsay HS, Subbaraju GV. Assessment of bioactivity of indian medicinal plants using brine shrimp (artemia salina) lethality assay. Int J Appl Sci Eng 2005; 3(2): 125-134.

19. Collins PJ. Resistance to grain protectants and fumigants in insect pests of stored products in Australia. in Proc Austral Postharvest Technical Conf. 1998. CSIRO, Canberra, Australia.

20. Tabassum R, Naqvi S, Azmi M, Nurulain S, Khan M. Residual effect of a neem fraction, nimolicine and an insect growth regulator, dimilin, against stored grain pest Callosobruchus analis. in Proceedings of the Pakistan Congress of Zoology. 1997.

21. Thomsen WJ, Bioassay techniques for drug development. 2001: Harward academic Publisher.

22. Juario-Juzavil ME, Olga N, Mylene U. Effect of Phyllanthus niruri and Passiflora foetida Extracts on the Mortality and Survival rate of the Brine Shrimp Artemia salina. Res J Recent Sci 2015; 4(2): 61-67. 